\title{
Post 9/11 American Novel: Political Orientations in Representing Arabs
}

\author{
Mubarak Altwaiji \\ Northern Border University, Arar, Saudi Arabia \\ mubarak2006ye@gmail.com
}

\begin{abstract}
September 11, 2001 has been the most aggressive day in the history of modern America. The physical and psychological damages caused by the attacks left a unique experience of the day in the mind of American writers. Therefore, if literary and political orientations changed after the 9/11, novel's subject matter and themes changed too, because novel is a reflection of its social and political context. This study examines the assumption implicit in the dominant conceptions that novel serves the state's politics in its pursue of interests through representations and misrepresentations of other nations. This study examines how American novel expresses solidarity with the state and its politics, ignoring its imperial and hegemonic attitude towards other nations. Novel has become the most effective genres to represent the feelings of the nation and the concern of the country. Analysis will refer to two novels, Extremely Loud and Incredibly Close and Falling man, which directly deal with the moments of destroying the World Trade Centre and manifestly identify the terrorists, their culture, their religion and their intentions. Tendency to such themes allows American novel to follow the mainstream politics without grappling with the state's ideologies, interests and politics. Discussion will focus on the Foucauldian approach to literature and power and on the implications of using the Foucauldian approach to the study of imperial literature.
\end{abstract}

Keywords: 9/11 attacks, American novel, Arabs, Politics, terrorism

\section{Introduction}

Nations' narratives of any period reflect the wide horizons, interests and policies of the state. Novel is no exception. Novel is an essential element in the formation of the national identity and expression of its intellectual life and national unity. Further, novel of any period reflects the national awareness and concern about major national issues of that time. This socio-political context of American novel, according to Ip (2011), influences the themes, subject matters and meanings of the texts: "This trend has only become more pronounced since the attacks of September 11, 2001, and the resulting increase in public concern and interest about these subjects" (p. 209). 
American novel becomes a critical concept for those who are interested in investigating the American imperialism in the Middle East, though, American orientalism has existed for two and a half centuries and flourished as a discipline using the methods and techniques of the classic European orientalism. Foucault (1977) suggests that a strong relationship between power of the state and knowledge strongly exists; and indeed, that both have equal power to play on one another:

We should admit rather that power produces knowledge (and not simply by encouraging it because it serves power or by applying it because it is useful); that power and knowledge directly imply one another; that there is no power relation without the correlative constitution of a field of knowledge, nor any knowledge that does not presuppose and constitute at the same time power relations (p. 27).

The social and intellectual awareness in national issues has resulted in constructing power as a national demand in post 9/11 American novel and imposed a shift in its subject matter from pleasant literature to informative and instructional narratives. Conception of power of the state in modern American novel prospers and retains themes implicit in post $9 / 11$ politics. The main assumption in this study is that post 9/11 American novel is easily swayed by the political regimes in order to follow the mainstream politics without clashing with the state's ideologies and imperial ambitions. In novels like Extremely Loud and Incredibly Close and Falling Man, American writers represent the state's attitude towards issues of Arab Muslims, terrorism, Islam and mechanisms of fighting of terrorism. This acquired power in texts is the intellectual bodies assisting the state exercise its immanent imperial interests which are always "in the position of simultaneously undergoing and exercising this power" (Foucault, 1980: p. 98). According to Foucault, this power is not static but reproduced constantly as knowledge gets renewed:

If power seems omnipresent, it is not because it has the privilege of consolidating everything under its invincible unity, but because it is produced from one moment to the next, at every point, or rather in every relation from one point to another. Power is everywhere, not because it embraces everything, but because it comes from everywhere....Relations of power-knowledge are not static forms of distribution; they are "matrices of transformation"... subject to constant modification continual shifts (1990: p. 99).

The Foucauldian concept of power generation, as elaborated in the first volume of The History of Sexuality, is a perfect description of post 9/11 American discourses on different issues like representing cultures, terrorism and human rights which are 
different from previous literary discourses. Acquisition of this power is dynamic because of the existing relations between the states' interests and the intellectual discourses: "it is produced from one moment to the next, at every point, or rather in every relation from one point to another. Power is everywhere; not because it embraces everything, but because it comes from everywhere" (p. 93). Foucault assertion of this strong relationship in which a "discourse can be both an instrument and an effect of power" does also suggest that truth is produced through techniques and mechanisms of narration: "Indeed, truth is no doubt a form of power" (p. 101). This western approach to truth and power is reinforced by text as asserted by Plato:

... isn't it a bad thing to be deceived about the truth and a good thing to know what the truth is? For I assume that by knowing the truth you mean knowing things as they really are ... The philosopher is in love with truth, that is, not with the changing world of sensation, which is the object of opinion, but with the unchanging reality which is the object of knowledge (Scott, 2010: p. 8).

\section{Theoretical background}

The functionalist/structuralist display of power in literature involves the focus of writers on individuals, their culture, their intentions and their actual and observed behaviours. Manifestation of power is dynamic operating on different observable issues in different times. Dimension of truth, however, is central to the relationship between knowledge and power who both, of course, gain this truth by virtue of their relation. The basic premise of text's power theory hypothesizes that the writer's perception of the subject influences the way the subject is introduced (Foucault, 1972; Phillips \& Hardy, 2002). Lukes (1974) simplified the complexity of the semiotic relationship between power and text; and referred to the political relationship between the two. According to him, power of text can be exercised by misrepresenting the other, ignoring his attitudes and interests: " $A$ may exercise power over $B$ by getting him to do what he does not want to do...he also exercises power over him by influencing, shaping or determining his very wants" (p. 23). According to Gramsci (1971), this exercise of power can be interpreted as a form of 'cultural hegemony':

The methodological criterion on which our own study must be based is the following: that the supremacy of a social group manifests itself in two ways, as 'domination' [dominio] and as 'intellectual and moral leadership' [direzione]. A social group dominates antagonistic groups, 
which it tends to 'liquidate', or to subjugate perhaps even by armed force; it leads kindred and allied groups (p. 57-58).

Text in Foucauldian tradition is a place where power is exercised in order to "realize efficiency and reduce opposition through processes of regimentation, regularization and supervision" (Hiley, 1987: p. 346). This power is exercised through two processes: subjectification and perception. This approach is also accepted by Hoy (1981) who adopts a similar perspective to the Foucauldian style. According to Hoy, "power does not causally determine particular actions; it only makes them probable. So, A could have options open, and, similarly, both A and B would have different interests if they were not caught up in this net of ideological coercion (p. 51). Further, changes of roles and relations in the society are determinants of human discipline which is a "mechanism of control of the social body, a more effective spinning of the web of power over everyday life" (p. 54). This means that texts, representation and imagery are true only within a given determined discursive context.

Of course, this study assumes that there is an intentionality in adopting power in text because all representations are intended to deliver messages. Accordingly, authors become more radical humanists than radical structuralists or typical litterateurs because "radical humanism advocates an ideology that places people first" (Morgan, 1984: p. 320). The American encounter with the Arabs and Arab culture is clearly reflected in literary texts in which writers situate the majority of Arabs in the position of terrorists or at unprivileged positions. Writers become a part of the organization and locate themselves within the organization that demonstrates power:

\section{Contemporary American Literature about the Middle East is a tool for advancing certain policies by pressuring public opinions into accepting them through exaggerated propaganda. This propaganda is planned to enforce in the public mind that the Middle East is a chaotic part of the world, is uncivilized, and its inhabitants are backward Arabs who own oil but do not deserve it. Consequently, they need another power to teach them advancement, democracy and civilization, in short, to carry what the American public has come to know as "the white man's burden" (Al-Disuqi, 1992: p. 169).}

The strong relationship between novels and imperial hegemony is best understood as a theory of cultural hegemony which is indebted to both cultural and political theories. Post 9/11 American novel adopts divergent interests of the state and situates imperial interests in texts to rationalize the state's imperial interests and military retaliations abroad. Intriguingly, in the United States a stream of literature advocates the neoconservative interests of imperialism and hegemony over the Middle East. 
The overt theme of this literature is ultimately imperial: "cultural production of this period situates the American views in history and exposes the ways in which historical contexts influence the production of meanings" (Altwaiji, 2014: p. 314). In their investigation of post 9/11 American multi-culturalism, Rubin and Verheul argue that the fostering issues of hatred and hegemony in literature is the influence of political attitude in the country that "led Americans to recast their perceptions of diversity and assimilation within a national framework, and at the same time to reevaluate the position of the United States in the world" (2009: p. 7). This new leading position has marked a new stage in novel's symbolic power and the new geo-political realm novel represents.

\section{Post 9/11 Novel: A New Context}

The 9/11 aggressive attacks on the World Trade Centre and the Pentagon were both real and imaginary for people of Ground Zero and were perceived as a momentary victory of evil on goodness, backwardness on civilization and terror on peace. The attacks were brutal causing huge physical damages and psychological trauma. Demands of long-lasting memorials shaped symbolic actualities to represent the terrorists and their culture. The WTC, in addition to its publicity as a commercial centre and a house for many international offices, represents the American super position, capitalism, imperial power and cultural superego. The destruction of this symbolic power was perceived as an attack on the western power and culture. Kelley (2002) notes that 9/11 terrorist attacks are directed at "the principles and values of the West" and the terrorists' intention was "not the West as a society or a civilization per se, but rather the culture of modernity" (p. 5). This symbolism in action and retaliation during 9/11 and its aftermath result in literary responses that continue till the present day. These responses question the facts and fantasies of what happened, the terrorists and their culture; and insisted on a powerful imaginative representation. These representations thus widen the gap between the available classic volumes of representations in narrative and the new representations which become consensus opinion of both the writers and the state.

American novelists have taken up the concepts of national security, war on terror and American interests to represent the on-going political movement. Political themes on the national security, states' interests, world disorder, emergence of nasty radical groups in the Middle East, terrorist attacks and American retaliations are common to many writers who witnessed the horror of the day and become inspiration for emerging writers: "in the wake of 9/11 and the "war on terror" writers have reengaged with politics...political responses to $9 / 11 \ldots$ cultural policies have also seen 
increased attention. Political decisions after $9 / 11$ have had an undeniable impact on contemporary literature" (Kimberley, 2010). This focus on global issues is useful for neo-imperial and neo-colonial agendas and becomes reinforcing and antagonistic. It is a response to threats to the national security and is deeply informed by the twentyfirst American notions of power and high culture: "Americans from every walk of life unite in our resolve for justice... None of us will ever forget this day. Yet, we go forward to defend freedom and all that is good and just in our world" (CNN, Sep. 11. 2011). This relationship between text and politics has also been reassessed by a creative generation and thinkers who: "have begun to chart the difficult moral and ethical territory of the responsibilities inherent in any act of representation after 9/11" (Kimberley, 2010).

Insofar American politicians have to trigger blames on Arab culture; they "are often surrounded by controversy if they appear to be too pro-Arab," and similarly American writers found it difficult to write "objectively, honestly, and adequately" (Parker, 2008: p. 18). By describing the American reaction to the $9 / 11$ attacks as Crusades George W. Bush, the line between targeting terrorism as an ideology and the whole religion is blurred: "They [Muslims] hate what they see right here in this chamber...They hate our freedoms: our freedom of religion...They want to drive Christians and Jews out of vast regions of Asia and Africa...They stand against us" (BBC, 2001). This setting provides a quasi-detective platform for literary writers to follow:

...two aspects, violence and reciprocity, have come to characterize the dominant image of Islam in the West in recent times: violence in the widespread prevalence of targeted killings, riots, bombings, and warfare that have devastated parts of the world; reciprocity in that Islam is no longer the passive tableau on which Westerners fashion an image" (Quinn, 2008: p. 166).

Post 9/11 American novel on Islam and Muslims expresses what is not representable before $9 / 11$ and participates in the larger cultural scale of representing the Muslims provided by politics of the state. Islam and Arab Muslims become subjects of enmity, hate and suspicion to the extent that even other brown nations like Indians particularly the Sikhs are mistakenly represented or even harassed. The cultural impact of 9/11 events has associated aggression, terrorism and savagery with Islam and Arab Muslims and resulted in a critical examination of the religion itself. The Middle East, its people and culture become a distinctive valuable phenomenon and most vulnerable entities to representation. This vulnerability of Arab Muslims makes an Arab feel this 'cultural violence' is intertwined with what seems to be 'neo- 
imperial ambitions', just as the classic orientalism is intertwined with classic colonization.

\section{Don DeLillo's Falling Man (2007)}

Falling Man (2007) is about the national major issue of countering terrorism which lies in the depth of the people's psyche and becomes the most popular subject matter in this category of American fiction. The novel is concerned with terrorism, the terrorists and the culture they belong to. These themes are introduced through narrations from the victims' point of view on the ruthless nature of terrorism and its impact on the collective conscious. Falling Man opens with the survival of lawyer Keith Neudecker who escapes from the burning World Trade Centre with a slight injury in a "time and space of falling ash and near night" where he is "walking north through rubble and mud and there were people running past holding towels to their faces or jackets over their heads" (DeLillo, 2007: p. 3). The time is the morning of September 11, 2001 when the World Trade Centre is collapsing. The place "was not a street anymore but a world"; a world of horror in which "the roar was still in the air, the buckling rumble of the fall" and its people "running past holding towels to their faces or jackets over their heads...handkerchiefs pressed to their mouths...shoes in their hands" (p. 3). The cover of Falling Man, the image of World Trade Centre, gives glimpses of the horror- the "stink of fuel fire" and the "fitful cries of disbelief" and unpleasant views to the ugly nature of the attack which enrich the themes of the novel and solidify the narrative style. On 22 December 2001, DeLillo published In the ruins of the future: Reflections on terror and loss in the shadow of September in Harper's Magazine in which he refers to Islam as a major force pushing the terrorists to murder the non-Muslims:

These are the men who have fashioned a morality of destruction. They want what they used to have before the waves of western influence. They surely see themselves as the elect of God...It is the presumptive right of those who choose violence and death to speak directly to God. They will kill and then die...Allahu akbar. God is great (p. 37-40).

In Falling Man, Arabs living in the West are tested against the Western mind-set; a representation that corresponds with the discursive discourse of mainstream post 9/11 American neo-orientalism in which Arab mentality suffers confusion, uncertainty and disorder. DeLillo emphasizes the role of religion in the formation of terrorist identity by making his Muslim characters describe their own holy mission as a religious duty to gain martyrdom and Allah's reward of paradise. They read "the sword verses of the Koran" which inspired them to be "strong-willed, determined to 
become one mind...Become each other's running blood" (2007: p. 83). This clash with the Western culture becomes more apparent when these terrorists arrive in the secular Germany where everything "was twisted, hypocrite, the West corrupt of mind and body, determined to shiver Islam down to bread crumbs for birds" (p. 79). Falling Man criticizes the Arab rage against the secular West through cyclical images and fictional encounters and gives an effective characterization in different situations where Arabs' irrationality, violence and intolerance are evident: "They were in this country to pursue technical educations but in these rooms they spoke about the struggle...Hammad wasn't sure whether this was funny, true or stupid" (p. 79). Hammad, for example, one of the World Trade Centre's bombers, tells his group of terrorists about the Arab boy who was running in the mud toward the enemy position: "He took strength from this, seeing them cut down in waves by machine guns, boys in the hundreds, then the thousands, suicide brigades, wearing red bandannas around their necks and plastic keys underneath, to open the door to paradise" (p. 238). Arab terrorists share a common belief of death in the holy cause through Jihad against the non-Muslims and have to be very submissive to the religious instructions. In their world, people like Hammad, who is in the plane, follows the leader's instructions and forget the innocents, the world and the life:

Forget the world. Be unmindful of the thing called the world...Recite the sacred words. Pull your clothes tightly about you. Fix your gaz. Carry your soul in your hand...Every sin of your life is forgiven in the seconds to come. There is nothing between you and the eternal life in the seconds to come. You are wishing for death and now it is here in the seconds to come. He fastened the seatbelt. (p. 238-239)

Arabs' submission to Islam vouches the compelling dominance of the religion on Arab Muslims which affects their disposition to understand the cultural context they live in; even the liberal Arab Muslims share a considerable contrast with the west and its culture. Moreover, the Arab capacity for death in the cause of God or, at least, the phenomenon of hate feelings suggests that the Muslims are similar to one another, with a limited range of variation: "Bomb vest and black hood. We [Muslims] are willing to die, they [Westerners] are not. This is our strength to love death...The other side has a few men willing to die. God is great (p. 178). Islam is contextually defined by Amir, Hammad's fellow terrorist, as a "world outside the prayer room as well as the surahs in the Koran. Islam is the struggle against the enemy, near enemy and far, Jew first, for all things unjust and hateful, and then the Americans" (p. 79-80). This general attitude of the Muslims towards the west is an aversive response provoked by the vicarious effect of Islamic teachings, Quran, surah, death, Jihad and martyrdom. 
Character identification often invites skepticism, especially when the fictional characters are identified with historic figures despite the differences between both in all sorts of behaviors in obvious ways. Similarly, the context and the concepts of the representation matter; the two elements enhance the relevance of the subject represented. Falling Man makes reference to names of eminent religious figures in Islamic history like Mohammed and his companions while representing modern terrorists: "This was the house of the followers, that's what they called it, dar alansar, and that's what they were, follower of the Prophet" (p. 83). Said comments on the connotations of this discourse saying "[w]hat is bad about all terror is when it is attached to religious and political abstractions and reductive myths that keep veering away from history and sense. This is where the secular consciousness has to try to make itself felt" (2001). Fiction writers do not exert complete control over the internal and external responses to their texts paving the way for reactions against represented community: "it might be hard to find a taxi at a time when every cabdriver in New York was named Muhammad" (DeLillo, 2007: p. 28). Provoking antipathy towards historic characters invariably corresponds with what the general attitude of the state appears to be or invite which, in DeLillo's case increases empathetic resonance by emphasizing the long history of Islamic aggression against the non-Muslims.

Several aspects in American novel act as the staging ground for modern American politics and attempt to highlight real issues or what accounts as political acquiring a strong relationship with post $9 / 11$ politics; the foremost proponent of the two is: "[c]ombating terrorism and securing the U.S. homeland from future attacks" "use the power" and "the strength of the American people to remain resolute in the face of adversity" (White House, 2003: p. 1-2). Reframing the collective attitudes of writers is one aspect of this strategy, for example, in 2001 before the invasion of Afghanistan, Bush calls upon his citizens to appreciate the suffering of men and women in Afghanistan: "My fellow citizens...Afghanistan's people have been brutalized - many are starving, and many have fled. Women are not allowed to attend school...Religion can be practiced only as their leaders dictate" (CNN, Sep. 21. 2001). Similarly, in 2003 before invading Iraq, President Bush's address to Iraqis registers a new American attitude grappled with images: "We will deliver the food and medicine you need. We will tear down the apparatus of terror and we will help you to build a new Iraq that is prosperous and free...there will be no more wars of aggression" (Borger, 2003). These addresses reveal the ability of the state in making scholars engage in representing nations and go beyond the articulated political statements. For example, Jones (2008), the author of The Sword of Medina, struggles to bridge the gap between the political realm of state and the personal realm of knowledge on Islamic society in order to construct meanings of $9 / 11$ and symbolic notions of national unity. Jones (2008) notes that knowledge on Islamic societies is 
not a barrier that hinders representing the Muslims at this stage because writers' knowledge on Arabs and Muslims is available and updated:

In spring of 2002, when the U.S. sent troops into Afghanistan, I began hearing news about the reversals for women there under the Taliban, how girls were no longer allowed to go to school and women were required to wear burqas, how the windows of their homes had to be painted black so they could not be seen from the outdoors, etc. As a feminine, I was disturbed by these reports and I wanted to learn more. I knew very little about Middle Eastern culture or Islam at the time, so I read a few books about the Middle East by American journalists (p. 355-356).

Jonathan Foer's novel Extremely Loud \& Incredibly Close (2005) is the political spirit and the social consciousness of the post 9/11 period whose representation is associated with political identification, regardless of how the content and the truth are related. All the characters in the novel are grieving for the insecurity of the state and losses of dear lives. It is extremely loud that brings all the citizens, the state, the public efforts and feelings incredibly close. The world of Extremely Loud \& Incredibly Close is too melancholic and painful for the loss of almost three thousand people by the terrorist attacks of a small group of radical Arabs. The power of the narrative lies in its centrality of empathy which wins or at least changes the minds of the readers. Extremely Loud is a story a nine-year old boy named Oskar Schell who searches for healing from insomnia, depression and panic attacks after he loses his father, Thomas Schell who was a victim of the 9/11 terrorist attacks. Narration focuses on the moments the planes crash the towers causing huge losses of the lives:

....my brain started misbehaving, and the whole time I was imagining a plane coming at the building, just below us...I imagined the last second, when I would see the pilot's face, who would be a terrorist. I imagined us looking each other in the eyes when the nose of the plane was one millimetre from the building. I hate you, my eyes would tell him. I hate you, his eyes would tell me. Then there would be an enormous explosion, and the building would sway, almost like it was going to fall over, which I know is what it felt like from descriptions I've read on the Internet, although I wish I hadn't read them. Then there would be smoke coming up at me and people screaming all around me (Foer, 2005: p. 322-323).

Extremely Loud is a manifestation of the traumatic state of the public which is reflected by the readers' outraged reaction and to the author's perspective. It, further, 
represents the heroism of the Americans who, despite their well-crafted symbolism and texts' meanings, they are sticking to the state's politics and beliefs; unquestionably demonstrate the broad and callous political spectrum of the state. The perception of the world in this novel mirrors the world we hear about in post 9/11 American politics, media and newspapers. White heroes contribute to the readers' collaborative responsiveness and views on antiheroes and villains in a way that resembles the political leaders' views on their easterner rivals. The following narrative is both reinforcing and antagonistic: its premise is that Arabs are threat to the security of the nation; reflecting the socio-political realities of the present:

There was lot of stuff that made me panicky, like suspension bridges, germs, airplanes, fireworks, Arab people on the subway (even though I'm not racist), Arab people in restaurants and coffee shops and other public places, scaffolding, sewers and subway grates, bags without owners, shoes, people with mustaches, smoke, knots, tall buildings, turbans. A lot of the time I'd get that feeling like I was in the middle of a huge black ocean, or in deep space, but not in the fascinating way (p. 33).

Post 9/11 political literature is a manifestation of the rise of American nationalism; for the boy Oskar Schell, nationalism is to learn self-defense: "Self-defense was something that I was extremely curious about, for obvious reasons, and Mom thought it would be good for me to have a physical activity" (p. 2). Extremely Loud \& Incredibly Close focuses on the depth and complexity of Schell and his depression and takes the reader to a broader discussion of national concerns of insecurity and terrorism. The personal suffering of Schell, his resistance to the psychological disorder and his attempts to recover from insomnia inspire the whole society who share the same experience. These aspects of nationalism are explained by the effective force of resistance which is governed by personal orientations, rather than by the political concerns. According to Caruth whose work represents the transmission of personal traumatic experience: "history, like the trauma, is never simply one's own, that history is precisely the way we are implicated in each other's traumas" (1996: p. 23). Schell's obsessions with 9/11 attacks and their effect on the national level have affected Grandma who also suffers but manages to convey her nationalistic concerns in a repetitive way:

.... Planes going into buildings.

Bodies falling.

People waving shirts out of high windows.

Planes going into buildings.

Bodies falling. 
Planes going into buildings.

People covered in gray dust.

Bodies falling.

Buildings falling.

Planes going into buildings (Foer, 2005: p. 299).

Post 9/11 cultural hegemony is influenced by American neo-imperial agenda in the Middle East; it is defined by American orientation and discourse-power relationship: "discourse transmits and produces power; it reinforces it...Discourses are tactical elements or blocks operating in the field of force or relations" (Foucault, 1990: p. 101). This relationship allows a transmission of power to the public sphere through representations which results in the formation of social beliefs to categorize whole nations. Rhodes, Leslie and Tworek (2012) refer to transmission of the "mysterious mana (for good or ill)" that leads to sharing beliefs on groups of people. According to them, people tend to "view members of a category as sharing a deep, underlying, inherent nature, which causes them to be fundamentally similar to one another in both obvious and nonobvious ways" (p. 13526). They give an example:

...viewing category members as fundamentally alike allows a child to infer that if one tiger is ferocious, then other tigers will be too, even if the individual tigers look different from each other (e.g., orange and white tigers). Similarly, viewing category-linked properties as arising from an underlying nature allows children to infer that a baby tiger will inevitably grow up to be ferocious, even if it does not appear ferocious at birth (p. 13526).

Extremely loud is a product of its world, political circumstances and aggressive moments; it is a confrontation with the overwhelming power that shook the country and the citizens. Its message is the national solidarity. Of course, a pen, according to Foer, is "mightier than a sword" (2005: p. 138). This discourse is shaped by the war on terrorism and the national sentiments on the perpetrators; a common view in America that Arab Muslims are violent and aggressive. To this effect in general, Said (1977) holds skeptical and doubtful views on all the western representations of the east: "The value, efficacy, strength, apparent veracity of a written statement about the orient therefore relies very little, and cannot instrumentally depend, on the orient...the written statement is a presence to the reader by virtue of its having excluded, displaced, and made supererogatory" (p. 21). Both Extremely Loud \& Incredibly Close and Falling Man reflect the political and cultural circumstances they encounter and offer an understanding of the larger framework of the American hegemonic and neo-colonial agenda in the Middle East. 


\section{Conclusion}

American novel defines itself within the broader post 9/11 American cultural context which is based on the American political orientations as well as the relationship between politics and aesthetics, and between history and narratives. Representation of Arab Muslims in Extremely Loud \& Incredibly Close and Falling Man reflects the political attitude towards the Muslims drawn on a sweeping platform that, of course, likely inspires readers to make these category-based judgments on all the Muslims. Though reality in these novels doesn't touch the writers personally, it, however, is the concern of the state and embodies its realm of dominance and imperialism. In Extremely Loud, white characters are positioned in an emblematic nationalist position and their views match those of the politicians. Falling Man is an effort to understand the complexity of Arab Muslims' mentality and a quest for meanings to this cultural encounter. DeLillo (2001) refers to the importance of this encounter in his In the Ruins: "We need them, even the common tools of the terrorists, to set against the massive spectacle that continues to seem unmanageable, too powerful a thing to set into our frame of practiced response" (p. 34). The multitude of images in novel, of course, has engaged with multiple events and encounters; in addition to 9/11 events, many encounters like bombings of US embassies, Oklahoma bombing, and the Gulf Wars have effectively enriched these problematic images and allowed novel to follow the mainstream politics without grappling with the state's ideologies, interests and politics.

\section{Reference}

Al-Disuqi, R. (1992). The Muslim Image in Contemporary American Fiction. Islamic Studies. 31(2), 169-184.

Altwaiji, M. (2014). Neo-Orientalism and the Neo-Imperialism Thesis: Post-9/11 US and Arab World Relationship. Arab Studies Quarterly. 36 (4), 313-323.

BBC, (2001). Text: Bush address to Congress. BBC.com, Retrieved November 25, 2016 from: news.bbc.co.uk/2/hi/americas/1555641.stm

Borger, J. (2003). Bush gives Saddam and his sons 48 hours to leave Iraq. The guardian.

Retrieved April 12, 2016 from:

https://www.theguardian.com/world/2003/mar/18/iraq.usa1

Caruth, C. (1996). Unclaimed Experience: Trauma, narrative, And History. Baltimore: Johns Hopkins UP.

CNN, 2001, The text of President Bush's address-September 11, 2001. CNN.com. Retrieved September 12, 2016 from: edition.cnn.com/2001/US/09/11/bush.speech.text

CNN, (2001). Transcript of President Bush's address-September 21, 2001. CNN.com

Retrieved September 12, 2016 from:

http://edition.cnn.com/2001/US/09/20/gen.bush.transcript

DeLillo, D. (2007). Falling Man. New York: SCRIBNR. 
DeLillo, D. (2001). In the ruins of the future: Reflections on terror and loss in the shadow of September. Harper's Magazine. 303 (1819), 33-40.

Foer, J. S. (2005). Extremely Loud \& Incredibly Close. New York: Houghton Mifflin Company.

Foucault, M. (1972). The Archaeology of Knowledge and The Discourse on Language. New York: Pantheon Books.

Foucault, M. (1977). Discipline and punish: The birth of the prison. London: Allen Lane.

Foucault, M. (1980). Power/knowledge: Selected interviews and other writings by Michel Foucault 1972-1977. Ed. C. Gordon. New York: Pantheon.

Foucault, M. (1990). The History of Sexuality, Volume I: An Introduction. London: Penguin Books.

Gramsci, A. (1971). Selections from the Prison Notebooks of Antonio Gramsci. Ed. Quinton Hoare and Geoffrey N Smith. New York: International Publishers.

Hiley, D. R. (1987). Power and values in corporate life. Journal of Business Ethics. 6 (5), 343-353.

Hoy, D. C. (1981). Power, repression, progress: Foucault, Lukes and the Frankfurt School. Triquarterly. 52 (Fall), 43-63.

Ip, J. (2011). The Dark Knight's War on Terrorism. Ohio State Journal of Criminal Law. 9 (1), 209-229.

Jones, S. (2008). The Jewel of Medina. New York: Beaufort.

Kelley, D. (2002). 9/11 and The War Against Modernity. The Atlas Society. Retrieved October 25, 2016, from: https://atlassociety.org/commentary/commentary-blog/36539-11-and-the-war-against-modernity

Kimberley, E. (2010). Before and after 9/11: American Literature and Visual Culture. Paper presented at the a one-day conference at the University of Leicester. England, Leicester.

Lukes, S. (1974). Power: A radical view. London: Macmillan.

Morgan, G. (1984). Opportunities arising from paradigm diversity. Administration and Society. 16 (3), 306-327.

Mullins, M. (2009). Boroughs and Neighbors: Traumatic Solidarity in Jonathan Safran Foer's Extremely Loud \& Incredibly Close'. Papers on Language and Literature. 45 (3), 298-324.

White House, (2003). National Strategy for combating terrorism. Retrieved November 21, 2016. https://www.cia.gov/news-information/cia-the-war-onterrorism/Counter_Terrorism_Strategy.pdf

Parker, C. J. (2008). Before And After 9/11:The Portrayal Of Arab Americans in U.S. Newspapers. Florida: University Of Central Florida.

Phillips, N. \& Hardy, C. (2002). Discourse Analysis - Investigating Processes of Social Construction. California: SAGE Publications.

Quinn, F. (2008). The Sum of All Heresies. New York: Oxford University Press.

Rhodes, M., Leslie, S., \& Tworek, C. (2012). Cultural Transmission of Social Essentialism'. Proceedings of the National Academy of Sciences. 109 (34), 1352613531.

Rubin, D. \& Verheul, J. (2009). American Multiculturalism after 9/11 Transatlantic Perspectives. Amsterdam: Amsterdam University Press.

Said, E. (1977). Orientalism. London: Penguin.

Said, E. (2001). Islam and the West are Inadequate Banners. Theguardian.com. https://www.theguardian.com/world/2001/sep/16/september11.terrorism3 
Scott, G. G. (2010). Playing the Lying Game: Detecting and Dealing with Lies and Liars, from Occasional Fibbers to Frequent Fabricators. California: Praeger. 